GOSPODARKA SUROWCAMI MINERALNYMI - MINERAL RESOURCES MANAGEMENT

2016

Volume 32

Issue

Pages 5-24

DOI 10.1515/gospo-2016-0009

\title{
Zonation of deposits of hard coals of different porosity in the Upper Silesian Coal Basin
}

\section{Introduction}

In the area of the Upper-Silesian Coal Basin (USCB) local changes in certain qualities and properties of hard coals are observed, e.g. the degree of metamorphism of coals, which changes and increases with the depth from east to west. It results in the occurrence of coals of different quality, from thermal coal and coke coal to anthracites (Jureczka and Kotas 1995).

Porosity is an important parameter which characterizes physical properties of coal. It is a textural property of the rock mass and, together with other qualities, it significantly influences the behaviour of coal when it is mined and processed. The porosity of hard coals of the USCB area has undergone numerous tests (e.g. Strugała 2001). Tests of porosity conducted by Ceglarska-Stefańska et al. (1995) on 14 samples of different types of hard coals, from type 31 to 42 , showed that their porosity ranged between 3,65 and several per cent.

Uniaxial compression strength (UCS) is one of the more important geomechanical parameters which determines behaviour of coal when it is mined and processed. Thus, determination of the value of porosity and strength of the same coal samples makes it possible to use the knowledge to solve various problems concerning geological engineering, mining geomechanics and the underground mining industry.

* D.Sc., ** Ph.D., Główny Instytut Górnictwa, Katowice, Poland; e-mail: mbukowska@gig.eu; usanetra@gig.eu; mwadas@gig.eu 


\section{Coal-bearing series in the Upper-Silesian Coal Basin}

The Upper-Silesian Coal Basin was formed on the Upper Silesian Block where, between the Namurian and the youngest Westphalian, coal-bearing formations sedimented. That is how molasse deposits were created. Initially, they were of paralic and then of limnic origin. Molasse deposits follow a cyclic sedimentation pattern. It is expressed with a particular sequence of lithologic types of rocks and types of sediment beds. Hence, cyclothems look different in different parts of the basin. The differences also refer to the thickness of beds, which is between a few and a few dozen meters for each of them.

Hard coal seams occur in productive formations of the Upper Carboniferous (lower part of Namurian A to mid-Westphalian D). Coal seams repeated in the vertical profile, in cyclothems, mean that the equilibrium between the USCB ground subsidence and flow of new outside material filling the sedimentary basin, was an important factor influencing the creation of multi-seam coal-bearing series.

Hard coal belongs to the group of sedimentation rocks of organic origin. It was formed as a result of accumulating plant matter in the right environmental conditions. The organic matter underwent long-lasting processes, initially of biogenic metamorphosis (an open peat bog environment), and then of geochemical metamorphosis (Gabzdyl 1989). The proportion of coal in the productive stratigraphic series of the USCB is differentiated (Fig. 1). Most of the coal is deposited in the Mudstone Series and the Upper Silesian Sandstone Series, where over 3-metre-thick seams are deposited. A good example is seam 510, as it is over 20 metres thick.

The properties of coal depend on the properties of its components (Chodyniecka et al. 1993). The basic components of coal are macerals. Groups of macerals demonstrate different

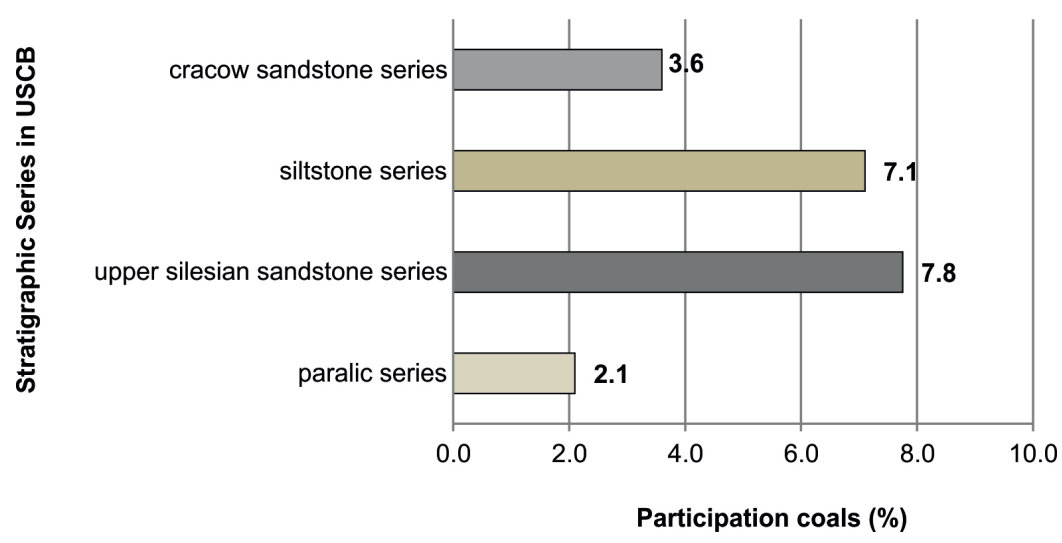

Fig. 1. Proportion of coals in stratigraphic series of the Upper Carboniferous USCB: Cracow sandstone series; siltstone series; Upper Silesian sandstone series; paralic series

Rys. 1. Udział węgli w seriach stratygraficznych serii węglonośnej GZW: krakowska seria piaskowcowa; seria mułowcowa; górnośląska seria piaskowcowa; seria paraliczna 
physical, chemical and technological properties. Moreover, the same group of macerals may also demonstrate variable properties (in different coals) depending on the degree of carbonization. Macerals form microlithotypes (aggregates in form of stripes). Their mineralized forms are carbominerites. Tests of hard coal lead to developing numerous concepts of its composition and structure models (Krevelen 1961; Nelson 1983; Seewald and Klein 1985; Walker et al. 1988; Lasoń, red. 1988; Kawęcka 1988; Jasieńko red. 1995; Czapliński red. 1994; Ndaji et al. 1997; Żyła red. 2000), and describing how different microlithotypes of coal behave as a result of injecting carbon dioxide into seams. Its also volume changes, resulting from sorption and desorption of gases (Baran and Zarebska 2015; Dutka et al. 2013; Karacan 2003; Karacan and Mitchell 2003).

\section{Tests of porosity and strength of hard coals USCB - methodology and results}

Coals of several stratigraphic members of the USCB were tested (stratigraphic classification of formations of GZW Upper Carboniferous by Kotas et al. (1988):

- Cracow sandstone series,

- siltstone series,

- Upper Silesian sandstone series,

- paralic series.

Hard coals were collected from 60 seams in 16 coal mines (Table 1). The mining areas located in different geological structures of the USCB, from the depth of between approximately 350 and $1200 \mathrm{~m}$. There were 81 samples tested altogether. A total of 447 measurements of uniaxial compression strength and 486 measurements of open porosity and bulk porosity were made. The tested coals have clarain, vitrain, more rarely the durain form, and they often contain inclusions of carbonates and sulphides. Examples of microscopic images of fragments of vitrain (Photo 1), clarain (Photo 2) and durain (Photo 3) are presented in Table 2 together with a short description of the petrography of the coal.

In hard coals, like in other rocks, there are voids which determine porosity and fissuring. Open pores determine open porosity in the space where liquids and gases flow. The total of open and closed porosity is referred to as bulk porosity.

Values of porosity were calculated applying equations contained in standard PN-EN 1936:2010, basing on results of density tests determined according to standard PN-G-04537 and bulk density determined according to standard PN-82/G-04537. Values of density were determined with the pycnometer method, applying class 3 water as pycnometer liquid determined according to standard PN-91/C-06510. Strength tests were conducted in servo control testing machine MTS 810 according to standard PN-G-0403: 1997. Tests of density and bulk density were conducted for, at least, three samples and compression strength for at least five.

Figures 2-7 present average values of porosity and uniaxial compression strength. 


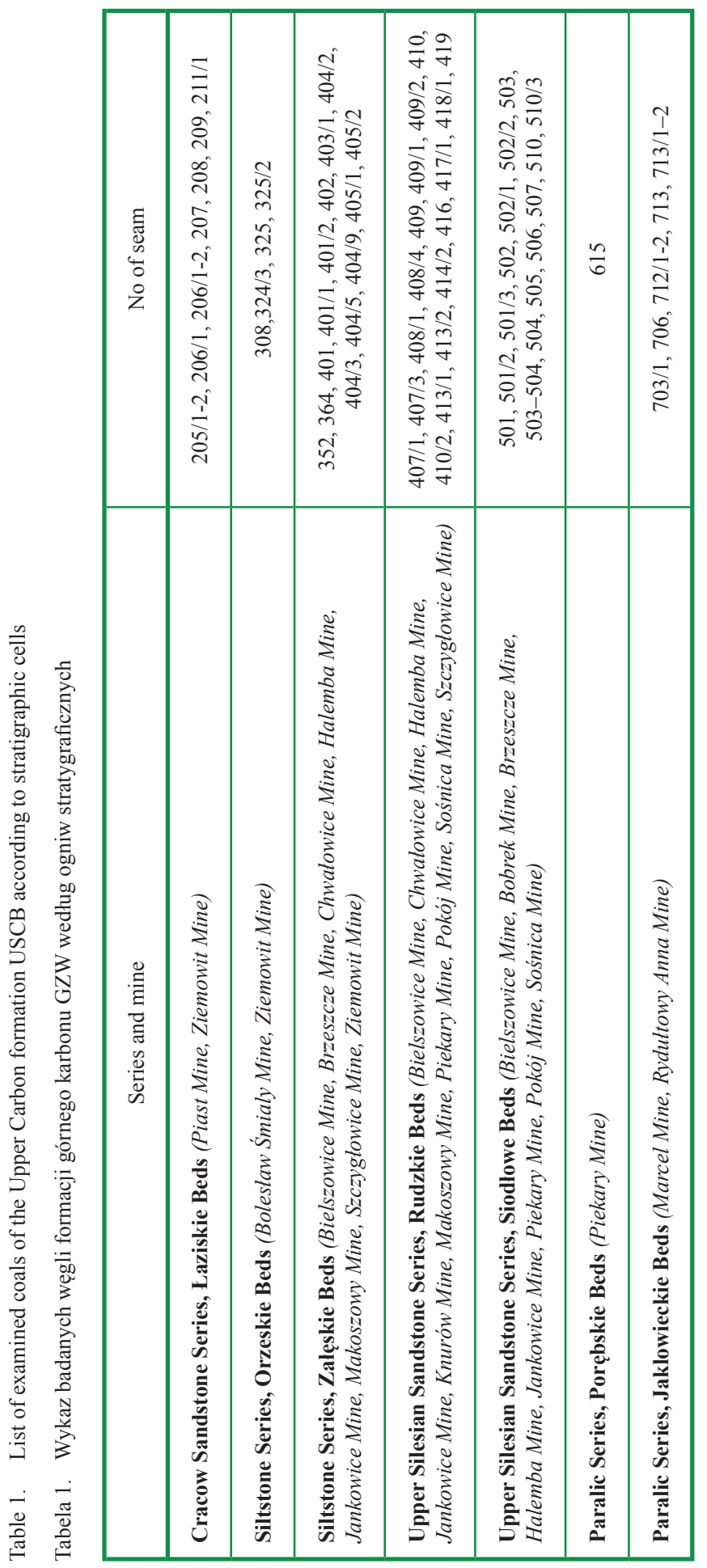


Table 2. Example of the petrographic composition of the main tested lithotypes of hard coal

Tabela 2. Przykład budowy petrograficznej przebadanych głównych litotypów węgla kamiennego

\begin{tabular}{|c|c|}
\hline $\begin{array}{l}\text { Microscopic image of a fragment of a coal } \\
\text { sample }\end{array}$ & Petrographic description of coal \\
\hline & $\begin{array}{l}\text { Sample of coal with a high content of vitrinite } \\
\text { ( } 75 \% \text { share), a relatively low share of liptinite }(5 \%) \text {, } \\
\text { inertinite }(15 \%) \text { and minerals }(5 \%) \text {. A large share of } \\
\text { macerals of the vitrinite group in the sample results } \\
\text { from a significant preponderance of vitrite }(62 \%) \\
\text { in the composition of microlithotypes. Clarodurite }(10 \%) \\
\text { and duroclarite (11\%) have significant shares, and other } \\
\text { microlithotypes have a few per cent share each. The } \\
\text { composition of microlithotypes is characteristic for vitrain. }\end{array}$ \\
\hline $\begin{array}{l}\text { Phot. } 1 \text {. Vitrite with weathering cracks } \\
\text { Fot. } 1 \text {. Witryt ze spękaniami wietrzeniowymi }\end{array}$ & \\
\hline & $\begin{array}{c}\text { Among macerals of the sample there is a dominant share } \\
\text { of vitrinite }(62 \%) \text {. The content of liptinite is } 12 \% \text { and of } \\
\text { inertinite, } 18 \% \text {. In the composition of microlithotypes, } \\
\text { duroclarite }(31 \%) \text { and vitrite ( } 30 \%) \text { have the biggest and } \\
\text { nearly equal share. The share of clarite and clarodurite is } \\
\text { approximately } 10 \% \text {. Other microlithotypes (vitrinertite, } \\
\text { inertite and durite) showed low contents in the coal - } \\
\text { a few per cent. Composition of microlithotypes is } \\
\text { characteristic for clarain. }\end{array}$ \\
\hline $\begin{array}{l}\text { Phot. 2. Duroclarite with pyrite concretions } \\
\text { Fot. 2. Duroklaryt z konkrecjami pirytu }\end{array}$ & \\
\hline$f$ & $\begin{array}{l}\text { Photo } 3 \text { shows a microscopic image of durain/fasain with } \\
\text { stripes of vitrain. The coal sample has a similar content of } \\
\text { vitrinite ( } 44 \%) \text { and inertinite }(40 \%) \text {. The content of liptinite } \\
(14 \%) \text { is also significant. High content of inertinite in the } \\
\text { sample, with a significant content of liptinite results from } \\
\text { the composition of the main microlithotypes. Together with } \\
\text { the dominant duroclarite }(41 \%) \text { there is high a content of } \\
\text { clarodurite }(25 \%) \text { and vitrinertite ( } 14 \%) \text {, with a high share } \\
\text { of inertinite. Microlithotypes of subordinate share } \\
\text { (between one and a few per cent) include vitrite, inertite, } \\
\text { clarite, durite and vitrinertoliptite. }\end{array}$ \\
\hline $\begin{array}{l}\text { Phot. 3. Clarodurite with pyrite veins } \\
\text { Fot. 3. Klaroduryt z żyłkami pirytu }\end{array}$ & \\
\hline
\end{tabular}


The youngest of the tested coals belong to the beds of the Cracow sandstone series. Coals of the Cracow sandstone series - Łaziskie Beds - have significant variability of compression strength (19.6-51.5 MPa) (Fig. 2), the highest values of open porosity (5.9-12.5\%) and bulk porosity (10.5-17.3\%) among the tested coals of different stratigraphic groups.

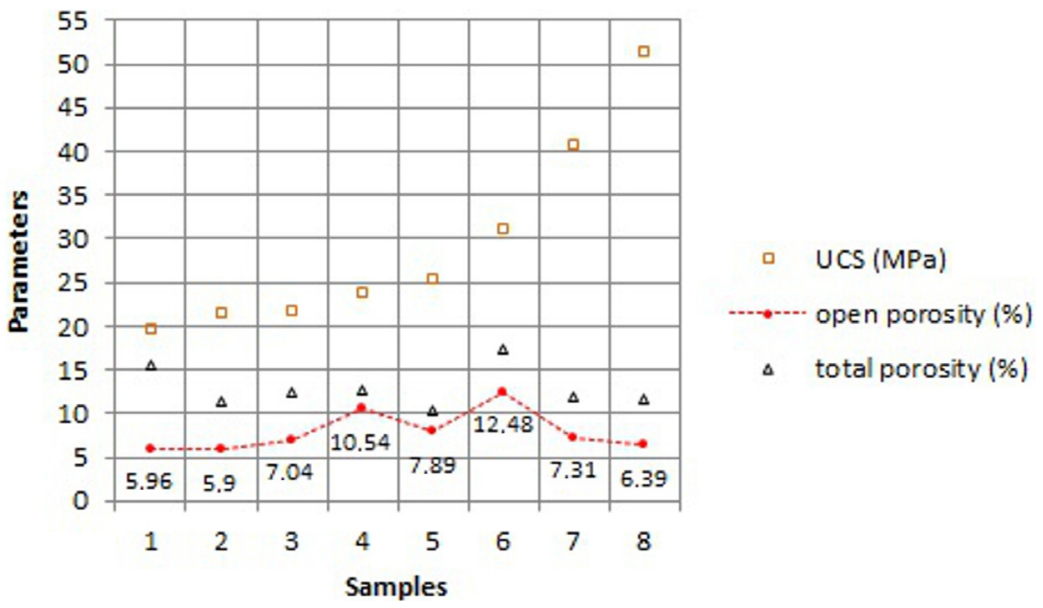

Fig. 2. Porosity and compression strength of coals of the Cracow sandstone series, Łaziskie Beds

Rys. 2. Porowatość i wytrzymałość na ściskanie węgli krakowskiej serii piaskowcowej, warstwy łaziskie

In the siltstone series coals - Orzeskie Beds - values of variability are low for both compression strength among the tested coals (12.1-14.0 MPa) and open porosity (between 4.22 and $6.65 \%$ ) (Fig. 3). The exception is a sample of coal of very high strength of $34.4 \mathrm{MPa}$, with open porosity of over $8 \%$. Values of total porosity are at a similar level of $10.76-13.42 \%$.

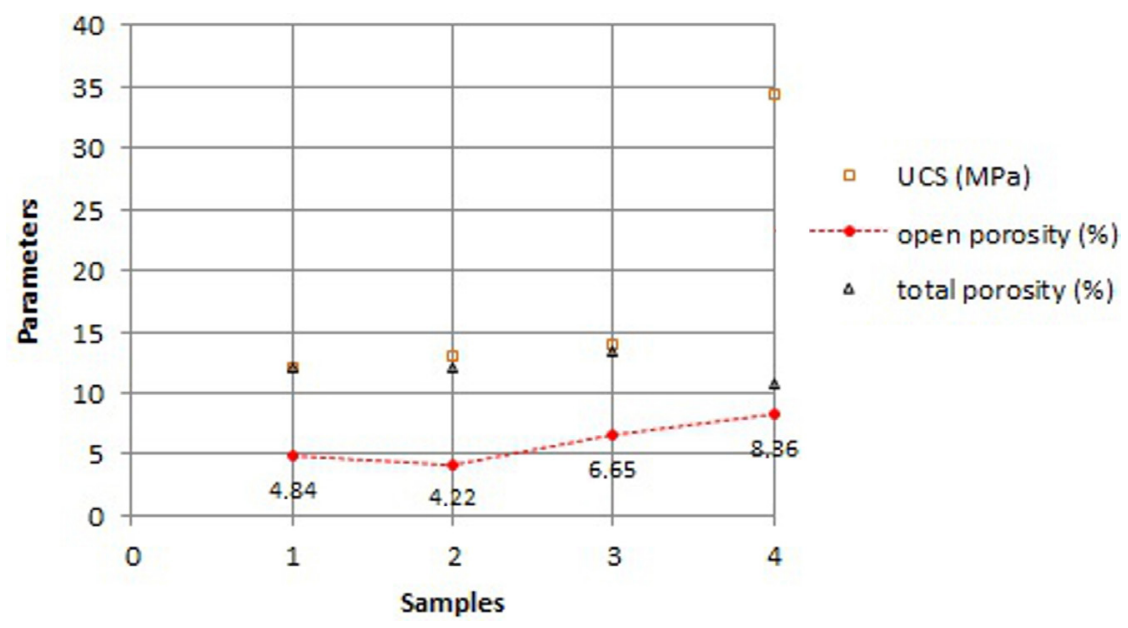

Fig. 3. Porosity and compression strength of coals of the siltstone series, Orzeskie Beds

Rys. 3. Porowatość i wytrzymałość na ściskanie węgli serii mułowcowej, warstwy orzeskie 
Coals of the Siltstone Series - Załęskie Beds - show differentiated values of compression strength between 9.7 and $28.3 \mathrm{MPa}$. The values of open porosity are between $1.63 \%$ and $7.95 \%$. It is characteristic for coals of this group, that coals of lower strength have a higher value of open porosity. Values of total porosity are much more differentiated, ranging from 3.65 to $12.97 \%$ (Fig. 4).

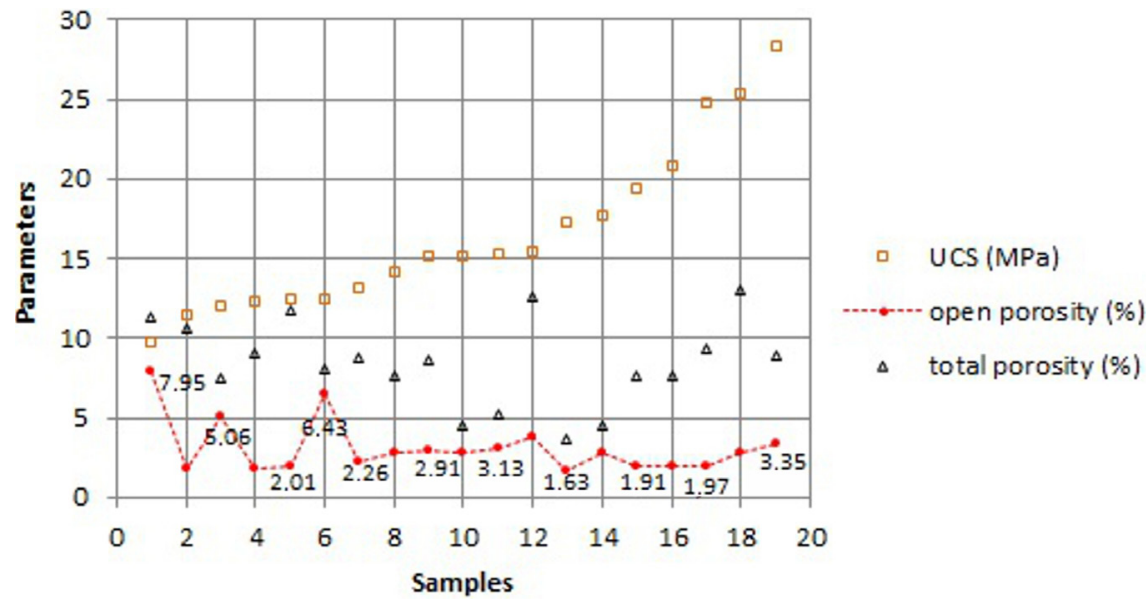

Fig. 4. Porosity and compression strength of coals of the siltstone series, Załęskie Beds

Rys. 4. Porowatość i wytrzymałość na ściskanie węgli serii mułowcowej, warstwy załęskie

In coals of the Upper Silesian Sandstone Series - Rudzkie Beds - the value of strength changes from 8.1 to $26.7 \mathrm{MPa}$. The value of open porosity is within the range between 1.46 and $6.37 \%$ (Fig. 5). There is significant variability of the total porosity value, which ranges from $4.34 \%$ to $17.45 \%$.

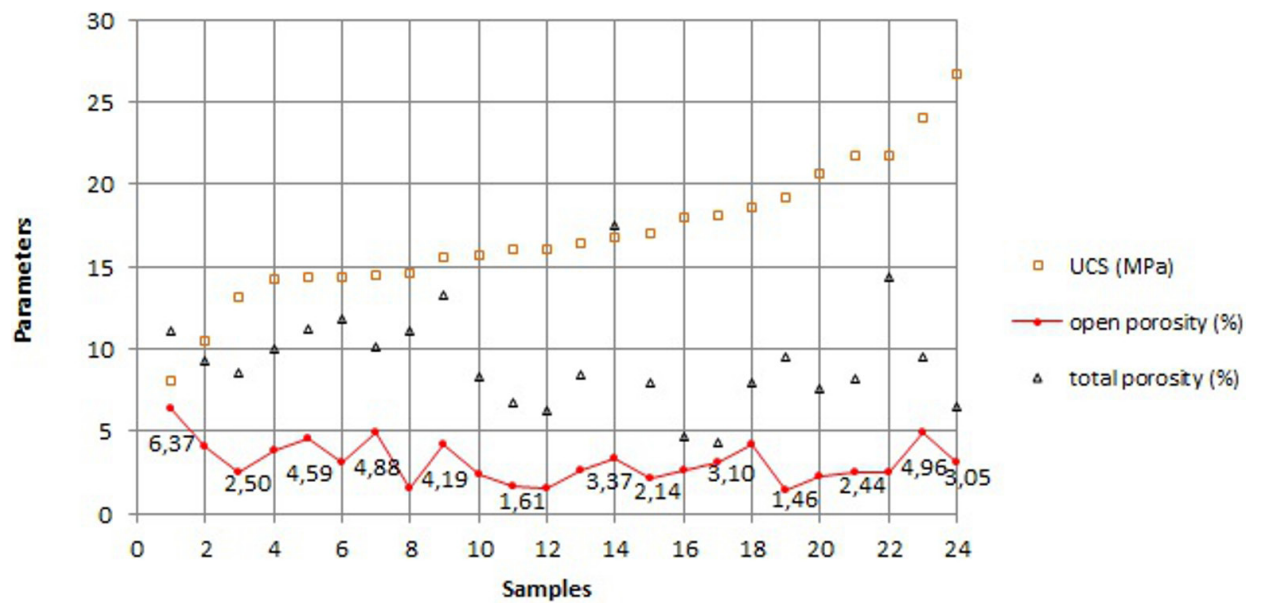

Fig. 5. Porosity and compression strength of coals of the Upper Silesian sandstone series, Rudzkie Beds

Rys. 5. Porowatość i wytrzymałość na ściskanie węgli górnośląskiej serii piaskowcowej, warstwy rudzkie 
Coals of the Upper Silesian sandstone series - Siodłowe Beds - demonstrate compression strength between 8.4 and 28.2 MPa. The measured open porosity is between 0.68 and $6.37 \%$ (Fig. 6). The values of porosity have a wider range of between $3.29 \%$ and $16.06 \%$. Open porosity of $14-16 \%$ for coals of strength of over $20 \mathrm{MPa}$ also tends to increase.

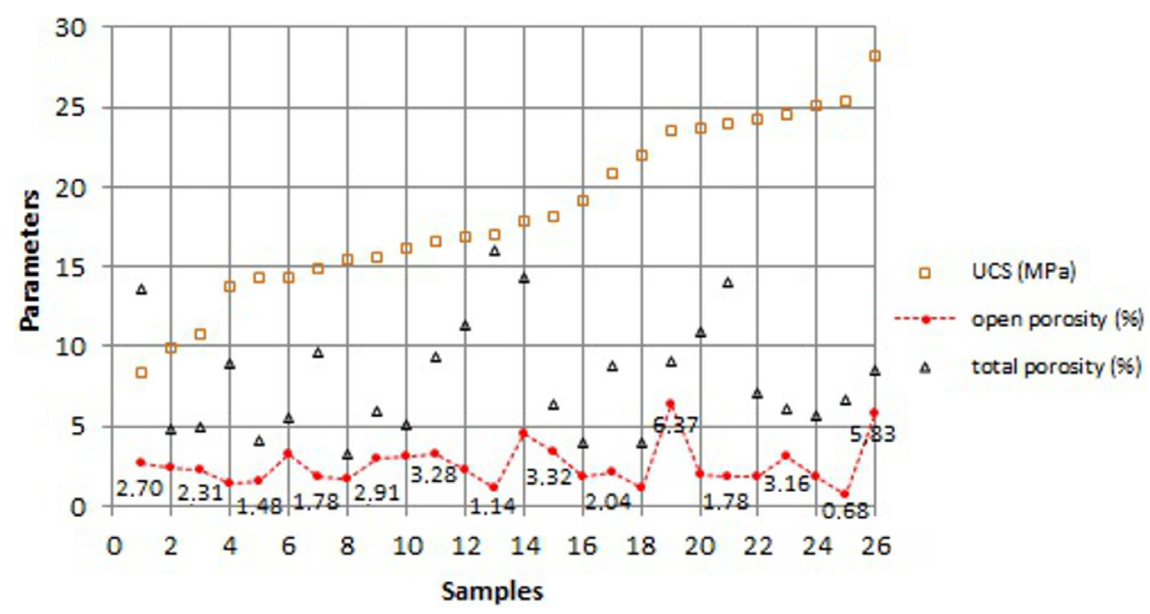

Fig. 6. Porosity and compression strength of coals of the Upper Silesian sandstone series, Siodłowe Beds

Rys. 6. Porowatość i wytrzymałość na ściskanie węgli górnośląskiej serii piaskowcowej, warstwy siodłowe

The oldest tested coals, which belong to the Paralic Series - Porębskie Beds and Jaklowieckie Beds - have compression strength of 10.6-22.1 MPa, which corresponds with low the strength class and high strength class (Bukowska 2012). The value of open porosity remains at a more or less steady level (from 0.68 to $2.38 \%$ ) (Fig. 7). The lowest value of open porosity is characteristic for the group of coals. The value of total porosity ranges from $4.07 \%$ to $14.25 \%$.

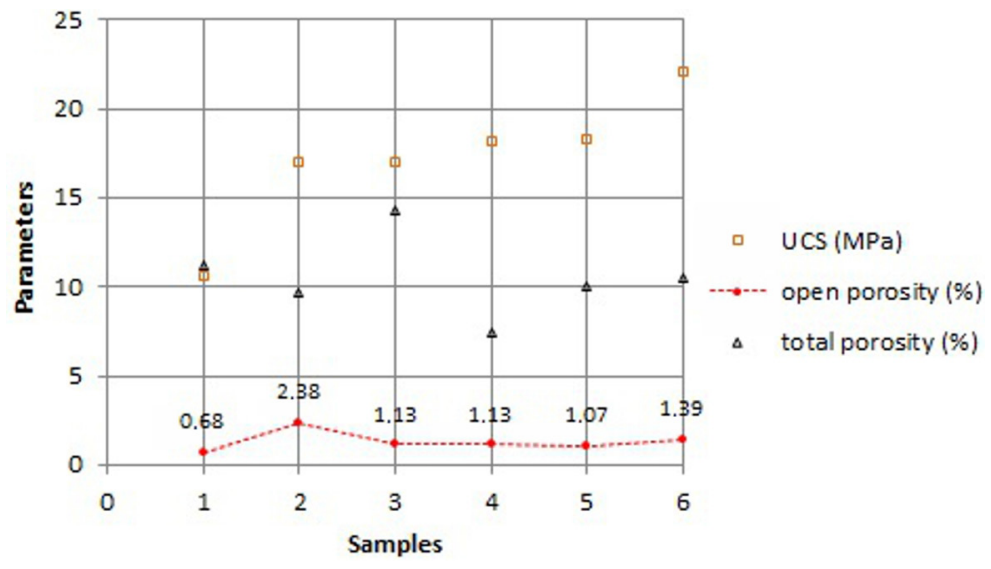

Fig. 7. Porosity and compression strength coals paralic series, Jaklowieckie Beds

Rys. 7. Porowatość i wytrzymałość na ściskanie węgli serii paralicznej, warstwy jaklowieckie 


\section{Chronostratigraphic and depth variability of properties of hard coals}

Coal samples were collected from different depths, from 350 to approximately 1200 metres. Taking into consideration the full lithostratigraphic profile of the USCB, generally, the number of seams increases with the depth. Variable geologic composition of the USCB makes it impossible to determine a characteristic steady range of deposition depth for any given group. Ranges of variability of deposition depth, value of compression strength, open porosity of coals and mean values for given stratigraphic groups are presented in Table 3. The small number of coal samples collected from the Porębskie Beds (seam 615) results from the limited scope of mining works conducted in the layers.

Uniaxial compression strength of the tested coals is between the very low strength class and the very high strength class (from 8.1 to $51.5 \mathrm{MPa}$ ) (Bukowska 2012). The most numerous group of the tested coals are the ones with compression strength of 10-30 MPa, with over $60 \%$ share in GZW. The uniaxial compression strength of the tested coals of the given stratigraphic groups is also within the ranges of variability determined for the conditions of the USCB. The obtained mean values of uniaxial compression strength are at the level of mean values determined for the given stratigraphic groups. An exception is the mean value of compression strength for coals of the Siodłowe Beds, which is below the mean value determined for coals of the beds in the whole area of the USCB.

The tests showed (Fig. 8) that an increase in depth is, in general, followed by a decrease in the open porosity of coals. There is an apparent decrease in open porosity in older hard coals. It was confirmed (Bukowska et al. 2012) that the lower and upper limits of ranges of variability of open porosity shift towards lower values for older coals, from Łaziskie Beds to Jaklowieckie Beds. The upper limit of open porosity decreases with the age of coals,

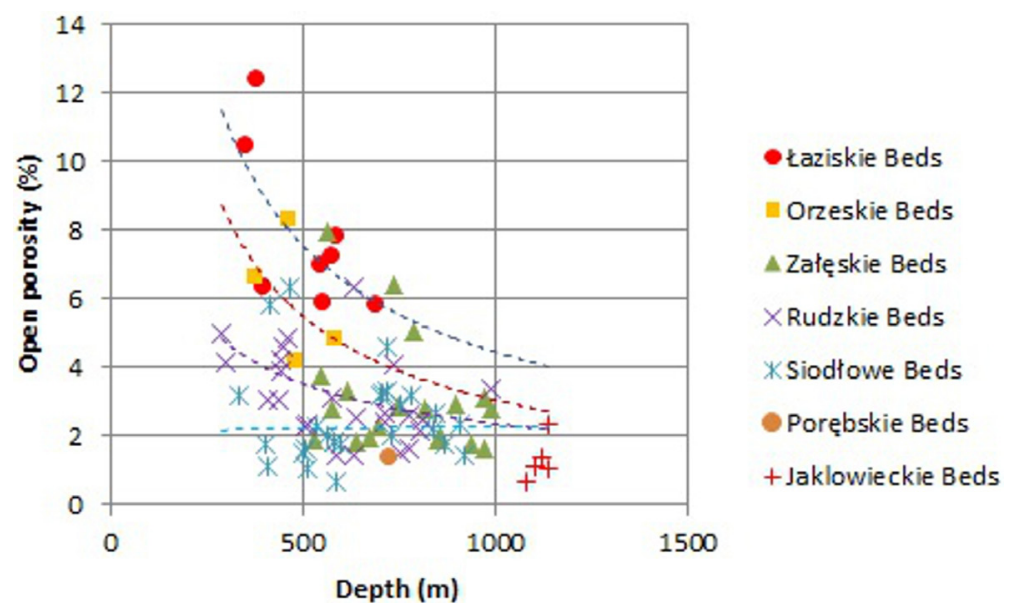

Fig. 8. Change in open porosity of hard coals in the USCB correlated with deposition depth of seams

Rys. 8. Zmiana porowatości otwartej węgli kamiennych w GZW z głębokością zalegania pokładów 
from the value of $12.48 \%$ characteristic for the Łaziskie Beds to the value of $2.38 \%$ characteristic for the Jaklowieckie Beds. For the youngest coals (Laziskie Beds and Orzeskie Beds) the dependence is particularly apparent at the depth of up to $700 \mathrm{~m}$.

Considering mean value of open porosity determined basing on the conducted laboratory tests (Table 3), Figure 9 shows the dependence of the coal open porosity value on the depth of a seam.

Table 3. Summary of values of open porosity of hard coals for stratigraphic groups

Tabela 3. Zmienność wartości porowatości otwartej węgli kamiennych w grupach stratygraficznych

\begin{tabular}{|c|c|c|}
\hline \multirow{2}{*}{ Stratigraphic groups } & Depth [m] & Open porosity [\%] \\
\hline & $\min -\max$ average & min-max average \\
\hline \multirow{2}{*}{$\begin{array}{l}\text { Laziskie Beds } \\
\text { seam } 200\end{array}$} & $345-684$ & $5.90-12.48$ \\
\hline & 502 & 7.94 \\
\hline \multirow{2}{*}{$\begin{array}{l}\text { Orzeskie Beds } \\
\text { seam 301-326 }\end{array}$} & $375-578$ & $4.22-8.36$ \\
\hline & 473 & 6.02 \\
\hline \multirow{2}{*}{$\begin{array}{l}\text { Załęskie Beds } \\
\text { seam 327-406 }\end{array}$} & $530-986$ & $1.63-7.95$ \\
\hline & 757 & 3.11 \\
\hline \multirow{2}{*}{$\begin{array}{l}\text { Rudzkie Beds } \\
\text { seam 407-419 }\end{array}$} & $288-986$ & $1.46-6.37$ \\
\hline & 598 & 3.15 \\
\hline \multirow{2}{*}{$\begin{array}{c}\text { Siodłowe Beds } \\
\text { seam } 500\end{array}$} & $330-922$ & $0.68-6.37$ \\
\hline & 633 & 2.53 \\
\hline $\begin{array}{c}\text { Porębskie Beds } \\
\text { seam } 600\end{array}$ & 720 & 1.40 \\
\hline \multirow{2}{*}{$\begin{array}{l}\text { Jaklowieckie Beds } \\
\text { seam } 700\end{array}$} & $1078-1140$ & $0.68-2.38$ \\
\hline & 1114 & 1.30 \\
\hline
\end{tabular}

Statistical analysis of the dependence between open porosity and depth was conducted with the Statistica software. The analysis showed that power function is the best-matched model of nonlinear regression. A report containing results is presented in Figure 10.

Considering logarithmic transformation LOG (x) the model assumes the following form:

$$
\begin{aligned}
\operatorname{LOG}(p)= & 5.81-1.878(D) \pm 0.13 \\
& (1.88) \quad(0.42) \quad \underline{\mathrm{R}^{2}=0.832}
\end{aligned}
$$

or the equivalent form:

$$
p=651567 D^{-1,878}
$$




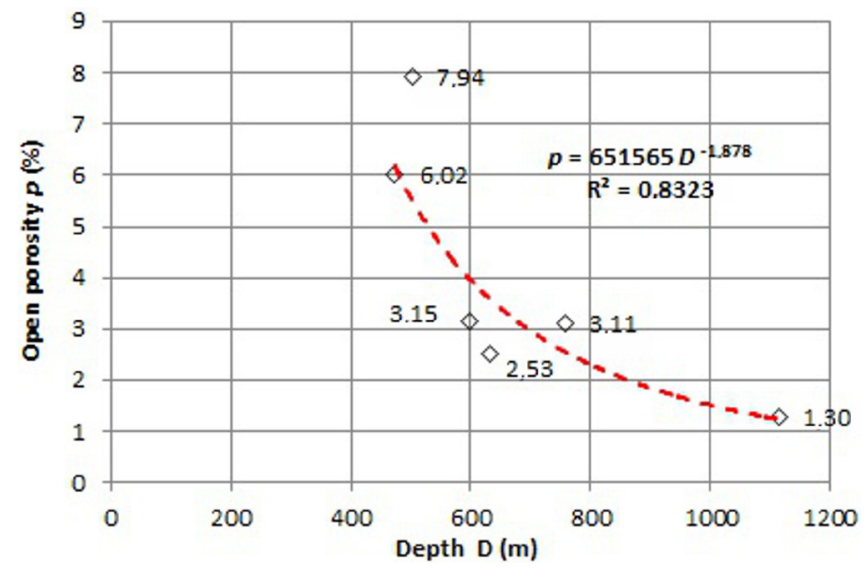

Fig. 9. Dependence value of open porosity on deposition depth of a coal seam

Rys. 9. Zależność wartości porowatości otwartej od głębokości zalegania pokładu węgla

\begin{tabular}{|c|c|c|c|c|c|c|}
\hline \multirow[b]{2}{*}{$\mathrm{N}=6$} & \multicolumn{6}{|c|}{$\begin{array}{l}\text { Podsumowanie regresji zmiennej zależnej: LOGV1 (p-h) } \\
R=.91233048 R^{\wedge} 2=.83234690 \text { Popraw. R2= .79043362 } \\
F(1,4)=19.859 p<.01119 \text { Błąd std. estymacji: .12796 }\end{array}$} \\
\hline & $b^{*}$ & $\begin{array}{c}\text { Bł. std. } \\
\text { z b* }\end{array}$ & $\mathrm{b}$ & $\begin{array}{c}\text { Bł. std. } \\
\text { z b }\end{array}$ & $\mathrm{t}(4)$ & $p$ \\
\hline W. wolny & & & 5.81396 & 1.186590 & 4.89972 & 0.008046 \\
\hline LOGV2 & -0.912330 & 0.204727 & -1.87778 & 0.421374 & -4.45632 & 0.011192 \\
\hline
\end{tabular}

Fig. 10. Statistica report

Rys. 10. Arkusz wyników

The coefficient of determination $\mathrm{R}^{2}$, which shows how well the model fits the data, informs what percentage of total changes in porosity is explained with a given assumed model. For the presented example it is $83 \%$. Normality of residuals (Fig. 11) was tested as well. Residuals, in general, are grouped either on the straight line or in its vicinity. The graph of the distribution of expected values, depending on observed values (Fig. 12), shows that expected values (open porosity) will be grouped on the line and in the area determined at a $95 \%$ confidence level.

In the tested youngest coals belonging to the Cracow sandstone series (Laziskie Beds) the average share of open porosity of porosity exceeds $60 \%$. In older coals, which belong to the siltstone series, the average share of open porosity in porosity is $41-55 \%$ (Orzeskie Beds and Załęskie Beds). Open porosity in coals of the Upper Silesian sandstone series (Rudzkie Beds and Siodłowe Beds) is approximately 35\% of porosity. In coals belonging to the paralic series (Porębskie Beds and Jaklowieckie Beds), the oldest ones 


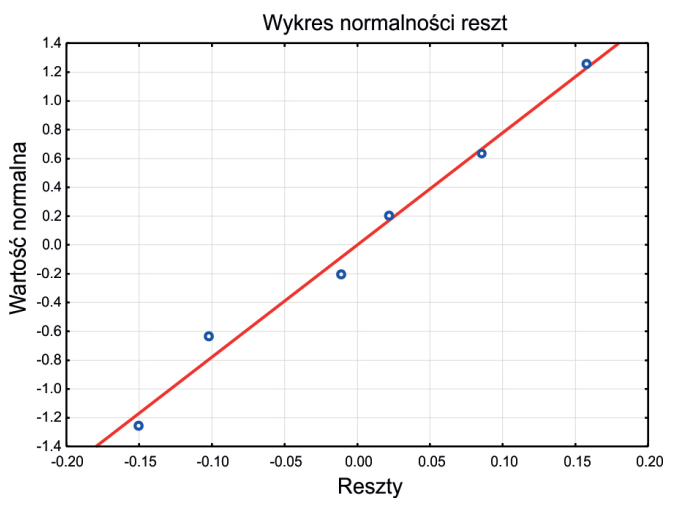

Fig. 11. Normality of residuals graph

Rys. 11. Wykres normalności reszt

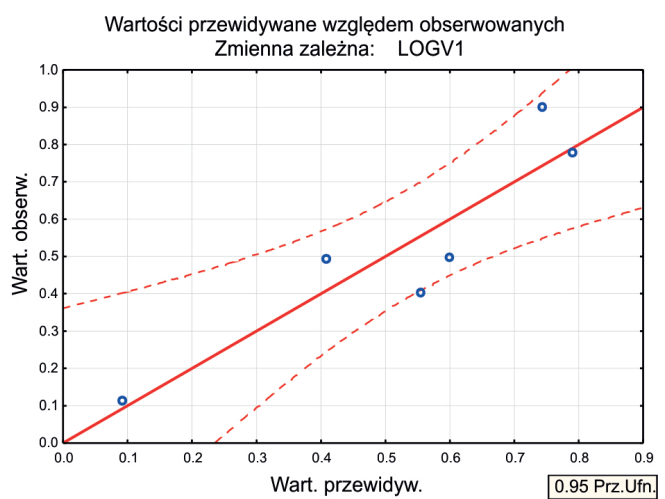

Fig. 12. Graph of expected values against observed values

Rys. 12. Wykres wartości przewidywane względem obserwowanych

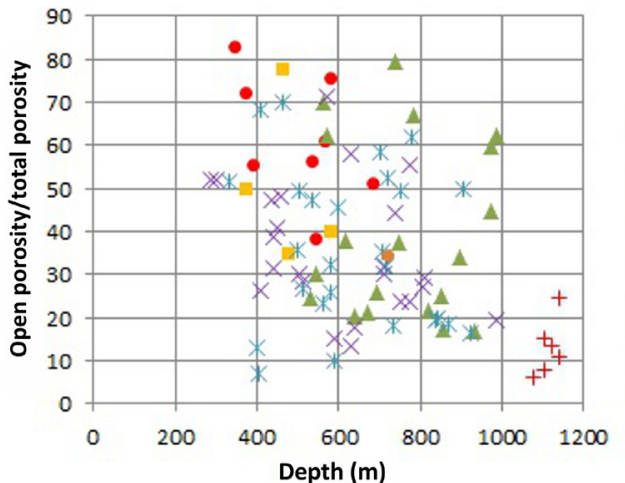

- Łaziskie Beds

$=$ Orzeskie Beds

$\triangle$ Załęskie Beds

$\times$ Rudzkie Beds

* Siodłowe Beds

Porębskie Beds

+ Jaklowieckie Beds

Fig. 13. Percentage share of open porosity in total porosity of coals depending on deposition depth

Rys. 13. Udział procentowy porowatości otwartej w porowatości całkowitej węgli w zależności od głębokości zalegania 
mined in the USCB, open porosity decreases and is, on average, merely an approximate $14 \%$ of total porosity. Having analysed average percentage share of open porosity in total porosity in the coals of the tested stratigraphic series, it was concluded that the older the coals, the lower share of open porosity in total porosity.

Considering percentage share of open porosity in total porosity in coals deposited at different depths, no decrease in the share of open porosity in total porosity, correlated to an increase in deposition depth of a coal seam, was observed (Fig. 13).

\section{Spatial variability of porosity of hard coals in the USCB}

Analyses of the full lithostratigraphic profile of the USCB show that, generally, numbering of hard coal seams increases with their deposition depth. The basin demonstrates complex lithostratigraphy and tectonics. Its complex structure means that older coal seams are not necessarily deposited deeper. No group of seams can be attributed a steady range of deposition depth in the vertical profile. It means that seams of the same age occur at different depths in different parts of the USCB and in different mining areas of coal mines.

The tests showed that open porosity was differentiated in coals of different age. Thus, it is possible to determine areas of the USCB where coals of different values of porosity are deposited. The zones are correlated with tectonics of the basin and the deposition of lithostratigraphic beds of a given age that are being mined (Fig. 14-17). Coals of seams occurring

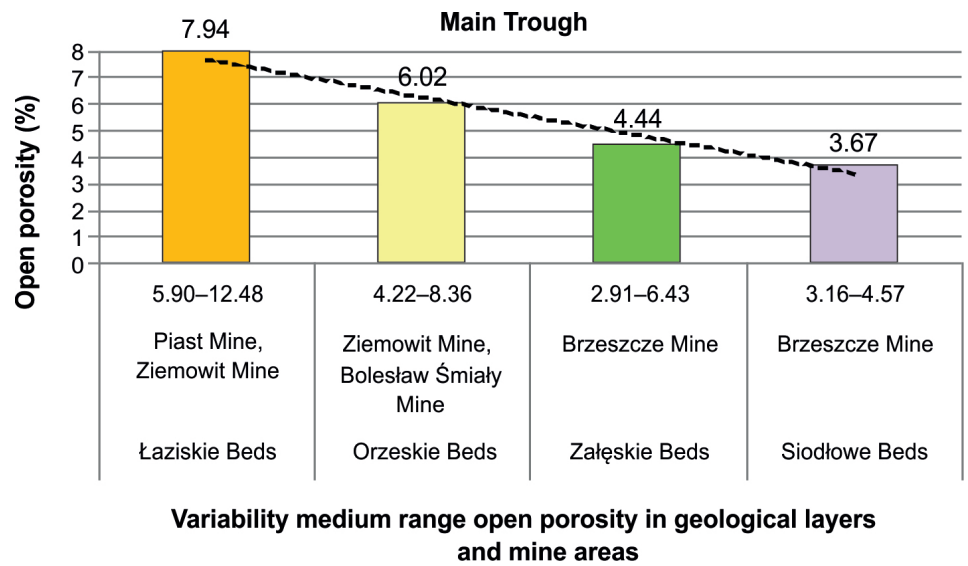

Fig. 14. Change in open porosity coals in the Main Trough of the USCB depending on their chronostratigraphic correlation

Rys. 14. Zmiana porowatości otwartej węgli w niecce głównej GZW w zależności od ich przynależności chronostratygraficznej 


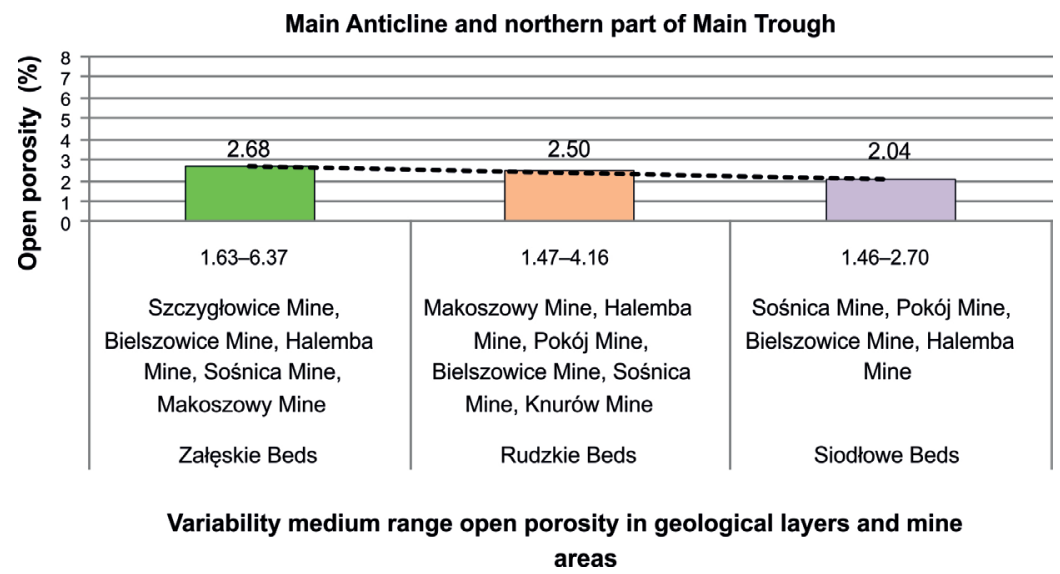

Fig. 15. Change in open porosity coals in the Main Anticline and the northern part of the Main Trough of the USCB depending on their chronostratigraphic correlation

Rys. 15. Zmiana porowatości otwartej węgli w siodle głównym i N części niecki głównej GZW w zależności od ich przynależności chronostratygraficznej

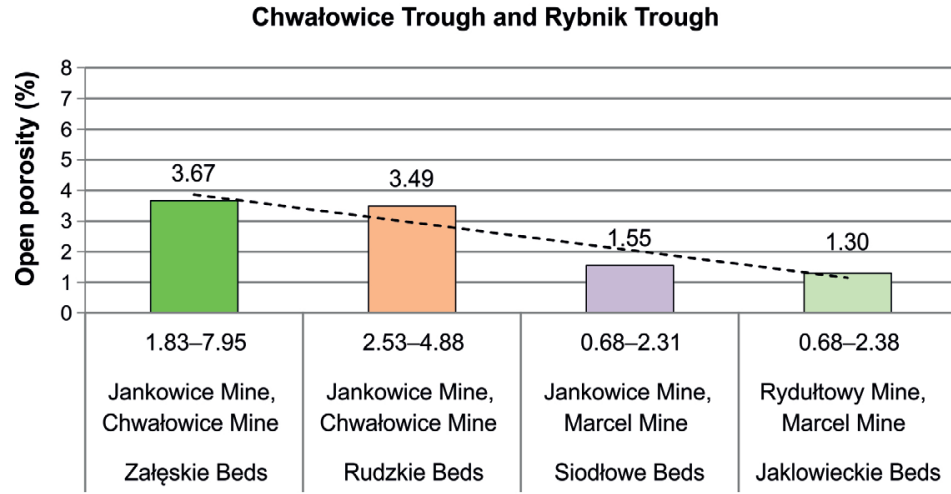

Variability medium range open porosity in geological layers and mine areas

Fig. 16. Change in open porosity coals in the Chwałowice Trough and the Rybnik Trough of the USCB depending on their chronostratigraphic correlation

Rys. 16. Zmiana porowatości otwartej węgli w niecce chwałowickiej i rybnickiej GZW w zależności od ich przynależności chronostratygraficznej

in the areas of the Main Trough, the Main Anticline and the area of the northern part of the Main Trough, the Bytom Trough, the Chwałowice Trough and the Rybnik Trough were tested. Coals of the above mentioned tectonic structures showed a decrease in open porosity as their geologic age increased. It also means a change in open porosity following an increase in depth within a given structural unit.

Based on the conducted laboratory tests of open porosity of hard coals of the USCB area, Figure 18 shows the variability of the value compared with the USCB Upper Carboniferous. 


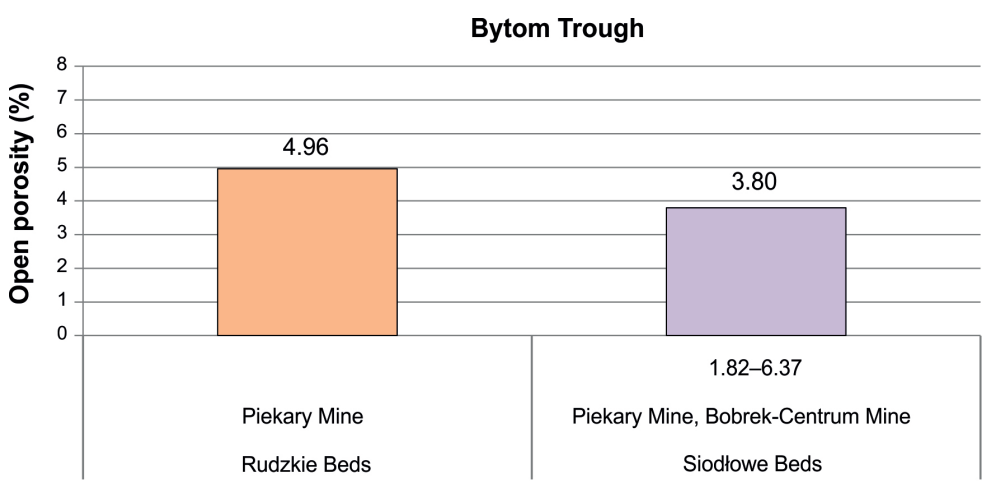

Variability medium range open porosity in geological layers and mine areas

Fig. 17. Change in open porosity coals in the Bytom Trough of the USCB depending on their chronostratigraphic correlation

Rys. 17. Zmiana porowatości otwartej węgli w niecce bytomskiej GZW w zależności od ich przynależności chronostratygraficznej

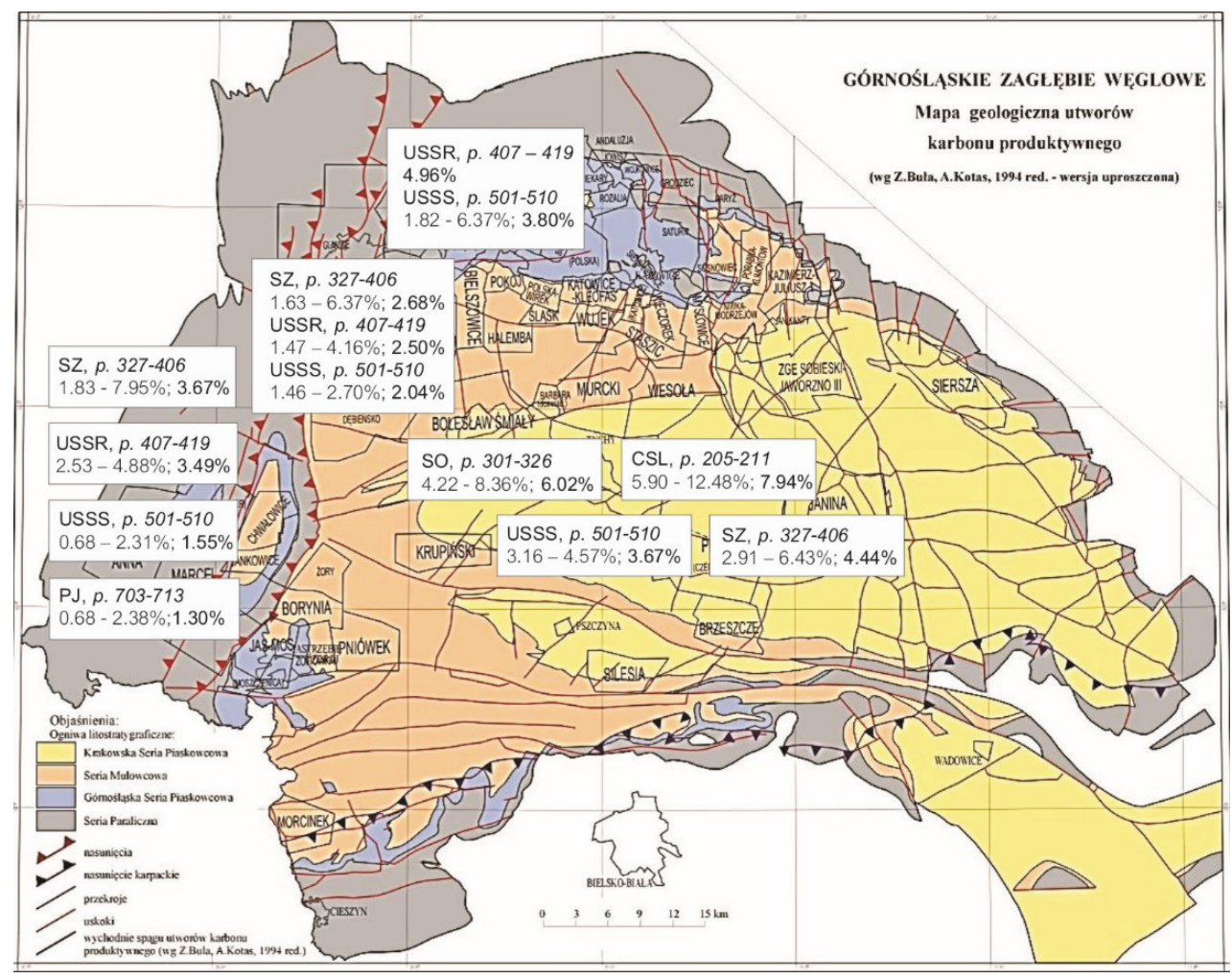

Fig. 18. Zonation of deposition of hard coals of different open porosity in the USCB (in Poland)

Rys. 18. Strefowość występowania węgli kamiennych o różnej porowatości otwartej w GZW (w Polsce) 


\section{Conclusions}

The coals of the Cracow sandstone series, the siltstone series, the Upper Silesian sandstone Series and the paralic series of the USCB were tested. Hard coals were collected in 60 seams of 16 coal mines of the Main Trough, the Chwałowice Trough and the Rybnik Trough, the Bytom Trough as well as from the Main Anticline, from the depth of approximately 350 to $1200 \mathrm{~m}$. A total of 486 open porosity and total porosity measurements and 447 uniaxial compression strength measurements were made.

Based on the results of the conducted tests it can be concluded that:

- The value of open porosity of the tested coals is $0.68-12.5 \%$, total porosity is 3.29 $-17.45 \%$ and their compression strength is in the very low strength class to the very high strength class (from 8.1 to $51.5 \mathrm{MPa}$ ).

- Coals of the Cracow sandstone series - Łaziskie Beds - demonstrate the highest values of open porosity (5.9-12.5\%), total porosity is greater than $10 \%(10.5-17.3 \%)$ and the biggest variability of compression strength (19.6-51.5 MPa). The oldest tested coals, which belong to the paralic series - Porębskie Beds and Jaklowieckie Beds - show the lowest values of open porosity, between 0.68 and $2.38 \%$, and remain at a more or less steady level. The total porosity for this stratigraphic group was $4.07-14.25 \%$.

- The lower and upper limit of ranges of variability of open porosity shift towards lower values for older coals from the Laziskie Beds to the Jaklowieckie Beds. The upper limit of open porosity decreases for older coals, from the value of $12.48 \%$ characteristic for the Łaziskie Beds to the value of $2.38 \%$ characteristic for the Jaklowieckie Beds. For the youngest coals (Laziskie Beds and Orzeskie Beds) the dependence is clearly seen up to a depth of $700 \mathrm{~m}$.

- With the age of coals the average share of open porosity in total porosity decreases from $60 \%$ (Cracow sandstone series - Łaziskie Beds), 41-55\% (siltstone series Orzeskie Beds and Załęskie Beds), 35\% (Upper Silesian sandstone series - Rudzkie Beds and Siodłowe Beds) to approximately $14 \%$ in the paralic series - Jaklowieckie Beds.

- The highest values of total porosity (over 10\%) were observed in the youngest coals (Cracow sandstone series and siltstone series). Older coals reached more diversified values of total porosity $(3.29-17.45 \%)$.

- Due to the fact that hard coal seams of the same age occur at different depths in different parts of the USCB and in different mining areas of coal mines, none of the groups of seams can be attributed a steady range of deposition depth in the vertical profile. Considering all the tested coals together, a stronger dependence of the value of open porosity on their chronostratigraphic setting (age of coal) than on the deposition depth was observed.

- Based on the conducted laboratory tests of porosity of the USCB hard coals, variability of the value was determined for the USCB Upper Carboniferous formations of 
different ages and deposition depth. Zones of deposition of coals of different porosity were determined. The zones are associated with the tectonics of the basin. Nevertheless, regardless of the correlation to a structural unit, the coals showed a decrease in open porosity following their geologic age. Thus, there is an apparent influence of coal deposition depth, within a given structural unit, on open porosity following the age of coal, i.e. correlation to an older chronostratigraphic unit.

- Such broad tests of the porosity of hard coals, correlated to their uniaxial compression strength and considering deposition depth of the seams and their correlation to chronostratigraphic units within given structural units in the area of the USCB with mining activity, had not been conducted before. The results of the tests have both research and practical implications.

\section{REFERENCES}

Baran, P. and Zarebska, K. 2015. Estimating the limiting absolute sorption of carbon dioxide by coal for coal-bed storage of carbon dioxide. International Journal of Oil Gas and Coal Technology Vol. 10, Is. 2, pp. 179-193.

Bukowska, M. 2012. Skłonność górotworu do tapań - geologiczne i geomechaniczne metody badań (Rock mass susceptibility to bumps - geological and geomechanical test methods). Wydawnictwo GIG. Katowice (in Polish)

Bukowska i in. 2012 - Bukowska, M., Sanetra, U. and Wadas, M. 2012. Chronostratigraphic and depth variability of porosity and strength of hard coals of Upper Silesian Basin. Gospodarka Surowcami Mineralnymi - Mineral Resources Management 28(4), pp. 151-166 (in Polish)

Chodyniecka i in. 1993 - Chodyniecka, L., Gabzdyl, W. and Kapuściński, T. 1993. Mineralogia i petrografia dla górników (Mineralogy and petrography for miners). Wydawnictwo Politechniki Śląskiej. Gliwice.

Ceglarska-Stefańska i in. 1995 - Ceglarska-Stefańska, G., Stachurski, J. and Vogt E. 1995. Porosity of the Polish Hard Coals. Archives of Mining Sciences 40(3).

Czapliński, A. red. 1994. Węgiel kamienny (Hard coal). Wydawnictwo AGH, Kraków (in Polish).

Dutka et al. 2013 - Dutka, B., Kudasik, M., Pokryszka, Z., Skoczylas, N., Topolnicki, J. and Wierzbicki, M. 2013. Balance of $\mathrm{CO}_{2} / \mathrm{CH}_{4}$ exchange sorption in a coal briquette. Fuel Processing Technology Vol. 106, pp. 95-101.

Gabzdyl, W. 1989. Geologia węgla (Hard coal geology). Skrypt Pol. Śl. nr 1427/2 (in Polish).

Jasieńko S. red. 1995. Chemia i fizyka węla (Chemistry and physico of hard coal). Oficyna Wydawnicza Politechniki Wrocławskiej Wrocław, pp. 221-261.

Jureczka, J. and Kotas, A. 1995. Tektonogeneza Górnośląskiego Zagłębia Węglowego (Tectogeny of Upper Silesian Coal Basin). [W:] The carboniferous system in Poland. Zdanowski, A. i Żakowa, H. ed). Prace PIG Vol. CXLVIII, pp. 168-171 (in Polish)

Karacan, C.Ö. and Mitchell, G.D. 2003. Behavior and effect of different coal microlithotypes during gas transport for carbon dioxide sequestration into coal seams. International Journal of Coal Geology 53, pp. 201-217.

Kawęcka, J. 1988. Struktura porowata węgli kamiennych (Porous structure of hard coals). Zeszyty Naukowe AGH nr 1212, Chemia z. 8, pp. 69-88 (in Polish).

Kotas i in. 1988 - Kotas, A., Buła, Z. and Jureczka, J. 1988. Problematyka podziału litostratygraficznego górnośląskiej serii piaskowcowej karbonu Górnośląskiego Zagłębia Węglowego w świetle zasad kodeksu stratygraficznego (Problems of lithostratigraphic divisi on of Upper Silesian Sandstone Series of Upper Silesian Carboniferous in the light of stratigraphic code). Materiaty XI Symp. Geologia Formacji Weglonośnych Polski, Formacja Karbońska. Wydaw. AGH. Kraków (in Polish)

Krevelen, D.W. 1961. COAL. Typology-Chemistry - Physics - Construction. Elsevier Publishing Comany. 
Lasoń, M. red. 1988. Sorpcja gazów i par a własności polskich węgli kamiennych jako układów dyspersyjnych (Sorption of gases and vapours properties of Polish hard coals as dispertion systems). Część I. Zeszyty Naukowe AGH, Chemia z. 8. Kraków (in Polish).

Ndaji et al. 1997 - Ndaji, F.H., Butterfild, I.M. and Thomas, K.M., 1997. Changes in the macromolecular structure of coals with pyrolysis temperature. Fuel 76, 169.

Nelson, J.R. 1983. Determination of molecular wight between crosslinks of coals from solvent - swelling studies. Fuel 62, 112 .

Seewald, H. and Klein, I. 1985. Methansorption an Stainkohle und Kennzeichnung der Porenstrukture. GluckaufForschungshefte, 47, 149 (in German).

Strugała, A. 2001. Porowatość węgli bitumicznych (Porosity of bituminous coals). Gospodarka Surowcami Mineralnymi - Mineral Resources Management 17(2), pp. 5-17 (in Polish).

Walker et al. 1988 - Walker, P.L., Verma, S.K., Rivera-Ultrilla, J. and Davis, A. 1988. Densities, Porosities and Surface Areas of Coal Maurals as Measured by their Interaction With Gases. Vapours and Liquids. Fuel 67, 1615 .

Żyła, M. red. 2000. Układ węiel kamienny-metan $w$ aspekcie desorpcji i odzyskiwania metanu z gazów kopalnianych (Hard coal - methane system in the aspect of desorption and capturing methane from mine gases). Uczelniane Wydawnictwa Naukowo-Dydaktyczne AGH, Kraków.

PN-G-0403: 1997. Skały zwięzłe. Oznaczanie wytrzymałości na ściskanie z użyciem próbek foremnych (Determining compression strength using geometric solid figure samples) (in Polish).

PN-EN 1936: 2010. Metody badań kamienia naturalnego. Oznaczanie gęstości i gęstości objętościowej oraz catkowitej i otwartej porowatości (Methods of testing minerals. Determining density and bulk density, bulk and open porosity) (in Polish).

PN-G-04537:1998. Węgiel kamienny i brunatny. Oznaczanie gęstości rzeczywistej (Hard coal and lignite. Determining real density) (in Polish).

PN-82/G-04537. Węgiel kamienny I brunatny. Oznaczanie gęstości rzeczywistej i pozornej (Hard coal and lignite Determining real density and bulk density) (in Polish).

\title{
STREFOWOŚĆ WYSTEPOWANIA WEGLI KAMIENNYCH O RÓŻNEJ POROWATOŚCI W GÓRNOŚLĄSKIM ZAGLĘBIU WĘGLOWYM
}

\author{
Słowa kluczowe
}

węgiel kamienny, porowatość, zmienność porowatości w GZW

\section{Streszczenie}

W artykule przedstawiono wyniki badań porowatości węgli kamiennych w Górnośląskim Zagłębiu Węglowym. Porowatość określono dla różnych litotypów węgla kamiennego, które pobrano z różnych rejonów Górnośląskiego Zagłębia Węglowego. Węgle kamienne pobrano z 60 pokładów w 16 kopalniach, z głębokości od około 350 do 1200 m. Przedstawiono zróżnicowanie wartości porowatości otwartej węgla od głębokości zalegania, pozycji chronostratygraficznej pokładu oraz przynależności do jednostki tektonicznej. Wytrzymałość na ściskanie przebadanych węgli mieści się w klasie wytrzymałości od bardzo małej do bardzo dużej (od 8,1 do 51,5 MPa), porowatość otwarta wynosi 0,68-12,5\%, a porowatość całkowita wynosi 3,29-17,45\%. Ze wzrostem głębokości, generalnie, porowatość otwarta węgli maleje. Zaobserwowano przesuwanie się dolnej i górnej granicy przedziałów zmienności porowatości otwartej w kierunku niższych wartości ze wzrostem wieku węgli, od warstw 
łaziskich do warstw jaklowieckich. Ze wzrostem wieku węgli średni udział porowatości otwartej w porowatości całkowitej wynosi od $60 \%$ dla węgli najmłodszych do zaledwie kilkunastu procent dla węgli najstarszych. Największe wartości porowatości całkowitej (powyżej 10\%) stwierdzono w węglach najmłodszych (krakowska seria piaskowcowa i seria mułowcowa). Węgle starsze osiągnęły wartości porowatości całkowitej od kilku do kilkunastu procent $(3,29-17,45 \%)$. Na podstawie przeprowadzonych badań wyznaczono w obszarze GZW strefy związane z tektoniką zagłębia i z występowaniem warstw litostratygraficznych określonego wieku, w których węgle kamienne różnią się wartościami porowatości. Jednakże, bez względu na przynależność do jednostki strukturalnej, węgle wykazywały zmniejszanie się porowatości otwartej wraz ze zwiększaniem się ich wieku geologicznego. Zatem jest obserwowany wyraźny wpływ głębokości zalegania węgla w obrębie danej jednostki strukturalnej na porowatość otwartą wraz ze wzrostem wieku węgla, czyli przynależnością do coraz starszej jednostki chronostratygraficznej.

Badania porowatości węgli kamiennych są publikowane w czasopismach naukowych, ale najczęściej brak jest informacji na temat rodzaju porowatości. Szczegółowa charakterystyka porowatości otwartej dla węgli Górnośląskiego Zagłębia Węglowego dotychczas nie była opracowana w zakresie, jaki jest przedstawiony w artykule i na tym polega oryginalność naszych wyników badań. Tak szerokich badań porowatości otwartej węgli kamiennych w powiązaniu z ich wytrzymałością i w odniesieniu do głębokości zalegania pokładów oraz przynależności do jednostek litostratygraficznych w obrębie poszczególnych jednostek strukturalnych w obszarze Górnośląskiego Zagłębia Węglowego dotychczas nie przeprowadzono. Uważamy to za wystarczającą argumentację podjęcia szczegółowych badań właśnie porowatości otwartej węgli kamiennych.

Wyniki badań mają znaczenie poznawcze i aplikacyjne. Znajomość porowatości węgla jest niezbędna do rozwiązywania wielu zadań inżynierskich z obszaru geoinżynierii, geomechaniki górniczej i górnictwa, na przykład w zakresie: oceny zachowania się węgla podczas eksploatacji oraz w procesie przeróbki, oceny możliwości uzysku metanu z węgla w rejonach występowania złóż bogatych w ten surowiec, który stanowi ponad 90\% składu gazu ziemnego, możliwości magazynowania lub składowania różnych substancji w rejonach zaniechania podziemnej eksploatacji węgla kamiennego (np. składowania $\mathrm{CO}_{2}$ w strukturze węgla), oceny możliwości wystąpienia niektórych zagrożeń naturalnych w wyniku eksploatacji złoża (np. zagrożenia wyrzutami węgla i skał), możliwości oceny zastosowania niekonwencjonalnych metod eksploatacji złóż węgla kamiennego (np. podziemnego zgazowania węgla).

\section{ZONATION OF DEPOSITS OF HARD COALS OF DIFFERENT POROSITY IN THE UPPER SILESIAN COAL BASIN}

$$
\text { Keywords }
$$

hard coal, porosity, variability of porosity in the USCB

$$
\text { Abstract }
$$

The article presents the results of tests of porosity of the Upper-Silesian Coal Basin (USCB) hard coals. The porosity was determined for various lithotypes of hard coal, collected in different areas of 
the Upper-Silesian Coal Basin. Samples of hard coal were collected in 60 seams of 16 coal mines, from the depth of approximately between 350 and $1200 \mathrm{~m}$. There are also presented differences in values of open porosity of coal depending on the depth of occurrence, as well as chronostratigraphic and tectonic correlation of a seam. Uniaxial compression strength of the tested coals falls in the strength class from very low to very high (from 8.1 to $51.5 \mathrm{MPa}$ ), open porosity is $0.68-12.5 \%$ and total porosity is $3.29-17.45 \%$. With an increase in depth, in general, open porosity of coals decreases. There is an apparent decrease in open porosity correlated with the age of hard coals. It was observed that the lower and upper limits of open porosity ranges of variability shift towards lower values the older the coals are, from the Łaziskie Beds to the Jaklowieckie Beds. The older the coals the greater the average drop in the share of open porosity in total porosity from $60 \%$ for the youngest coals to merely several per cent for the oldest ones. The highest values of total porosity (over 10\%) were observed in the youngest coals (Cracow sandstone series and siltstone series). Older coals reached more diversified values of total porosity (3.29-17.45\%). Based on the conducted tests, zones correlated with tectonics of the basin and with deposition of lithostratigraphic beds of specific age, where values of porosity of hard coals differ, were determined in the area of the USCB. However, in spite of their correlation to a structural unit, the coals demonstrated a decrease in open porosity with an increase in their geologic age. Thus, there is an apparent influence of the deposition depth of coal within a given structural unit on open porosity following the age of coal, i.e. correlation to an older and older chronostratigraphic unit.

Porosity tests of hard coal are published in scientific journals yet, most often, there is no information on the type of porosity. Such detailed characteristics of open porosity for coal of the Upper Silesian Coal Basin, as in the article, have not been prepared yet, making our research novel. Such broad tests of porosity of hard coals, correlated with their strength and referring to the deposition depth of seams as well as a correlation to lithostratigraphic units within individual structural units in the USCB, had not been conducted yet. We believe it is a sufficient argument to start detailed research into the open porosity of hard coals. The results of the tests are important from both the research and practical points of view. Knowledge of coal porosity is indispensable in solving many engineering problems of geological engineering, mining geomechanics and mining e.g.: assessing behaviour of coal when it is mined and processed, assessing the possibility of capturing methane, which makes up over $90 \%$ of natural gas, from coal in the areas of methane-rich deposits; the possibility of storing various substances in abandoned hard coal mining areas (e.g. $\mathrm{CO}_{2}$ storage within the structure of coal), assessing risk of occurrence of certain natural hazards resulting from mining deposits (e.g. coal and rocks outburst hazard), as well as assessing the possibility of applying unconventional methods of mining hard coal deposits (e.g. underground coal gasification). 